\title{
Methodology of conduction of a professional dialogue-questioning in Ukrainian language as foreign one at higher medical school
}

\author{
M. Tsurkan \\ Higher State Educational Establishment of Ukraine «Bukovynian State Medical University”, \\ Chernivtsi, Ukraine \\ Corresponding author. E-mail: maria-ts77@ukr.net
}

Paper received 11.11.19; Accepted for publication 22.11.19.

\section{https://doi.org/10.31174/SEND-PP2019-209VII86-13}

\begin{abstract}
The methodology of conduction of a professional dialogue in the process of studying of Ukrainian language as foreign one is considered in the article, the system of exercises is proposed and described, that is directed into development of dialogical communication in «a doctor - a patient» pair according to the modeled educational situation «At the dermatological department». Lexical minimum is proposed, that is optimal for communicative situation, the system of training exercises is developed for fixing an active vocabulary of foreign student, methods of construction of different types of interrogative sentences are detailed. The investigation is conducted on the basis of pedagogical experiment, that has been performed during practical lessons of Ukrainian language as foreign one at HSEI of Ukraine «Bukovynian state medical university» for students of the fourth course. Method of pedagogical observation was applied during the investigation, as well as method of theoretical analysis (at selection and examination of certain aspects of dialogical communication, at setting questions and formulation answers, peculiarities of Ukrainian lingual etiquette) and inductive method (at formulation of conclusion of investigation, which has been received by empirical (experimental) way). Training of foreign students to conduct a professional dialogue at Ukrainian language as foreign one lessons is a continuous process that provides students' motivation, mastering of basic vocabulary with its further inclusion into monologue communication, modeling of professional situation, distribution of roles of a doctor and patients, preparation and playing of a dialogue with further filling of medical card of a patient. The form of role games enlivens and diversifies educational process and promotes professionally oriented studying of Ukrainian language as foreign one in the process of preparation of a future highly qualified specialist. Conclusions of investigation are formulated on the basis of comparison of indicators of development of dialogical communication before and after conduction of pedagogical experiment, that has confirmed efficiency of proposed methodology.
\end{abstract}

Keywords: dialogical communication, dialogue-questioning, communicative competence, professionally oriented education, Ukrainian language as foreign one, motivation of a student-foreigner.

Introduction. Research of problems of formation of dialogical communication skills at Ukrainian language as foreign one lessons stays in the context of the most modern methodology-pedagogical studios above the specificity of individually-oriented approach to education, that consists in the change of didactic focus from a teacher to a student. «Ukrainian pedagogical dictionary» (1997) determines this approach «as consistent attitude of a pedagogue to a pupil as to personality, as to conscious responsible individual of selfdevelopment and as an individual of educational interaction» [Honcharenko, p. 243]. According to the majority of pedagogues, this approach helps self-awareness of personality in the best way, as well as self-realization and selfstrengthening and its application during studying of a foreign language forms long-term prospects of holistic formation of lingual personality, including Ukrainian language as foreign one, that opens the prospects of professional education. According to M. Arian (2007), «the formation of I-conception of students is one of motivating factors at studying of foreign language: students estimate obtained knowledge, lingual skills, and it expands their abilities in self-development in the future professional activity» [Ariyan, p. 47]. In addition, methodology of formation of skills of dialogical communication is integral part of the method of interactive education, and in its turn, it is based on interpersonal communication, the main aim of which is to develop the ability of communicative personality «to play the role of another one», to model specular perception of lingual act made by a partner, in the result of it, adequately estimate a situation and react».

The problems of skills formation of dialogical communication repeatedly became the subject of investigation for foreign and domestic scientists-pedagogues (I. Zymnia, Ye. Passov, I. Skliarenko, O. Vyshnevska, R. Fastovets, S. Andrushko, T. Oleinyk, M. Sosiak, J. Revel, G. Widowson and U. Littlewood, H. Pifo, M. Rivers, Fr. Debizer, and other). The system of exercises was proposed in these works, directed into development of skills of dialogical communication, psychological obstacles were considered in the process of such communication, a dialogue is considered in the system of coordinates of personalityoriented education. The researches of M. Arian, I. Berman, O. Tarnopolskyi, H. Bezpalova, L. Bidenko and of other scientists were dedicated to the development of dialogical communication at foreign language lessons at higher educational institutions of non-lingual profile. In particular, scientists L. Bidenko and H. Bezpalova (2017) justify expediency of application of audio-linguistic method of studying of Ukrainian language as foreign one at the initial stage: «The constant search of better ways of language learning and the technical progress inspire methodologists to invent new teaching methods and advance existing ones. In an attempt to correspond to the modern requirements, we applied the audio-lingual method of teaching Ukrainian language as foreign one at the initial stage. Here, the audio-lingual method is used together with other teaching methods (in particular, with the method of inverse resonance), that helps to reduce its drawbacks» [Bidenko, Bezpalova, p. 27]. However, not much attention is paid to phased formation of dialogue conduction skills in mentioned works, in particular, professional dialogue-questioning at higher medical school, that's why this investigation is needed now.

Foreign students, who obtain education in Ukraine, have the right to choose Ukrainian or English language system of education. The choice of Ukrainian language form of education provides speaking of Ukrainian language at the level that is not lower than B1, according to generally European lingual scale, that's why a student should study at preparatory department. Taking it into account, the majority of foreign students chooses English language form of education. In this case, a foreigner basically faces with two types of lingual difficulties, which are connected with everyday and professional adaptation. Students learn basic level of Ukrainian language possession during the first year of studying, that helps them to solve the row of problems of everyday life. 
However, the process of students' education comes out beyond university audiences and is implemented at clinical departments where practical lessons often provide conduction of a professional dialogue at the «a doctor - a patient» level at the third and fourth courses (depending on a faculty). This new lingual challenge that is connected with professional adaptation is much more complicated in comparison with students' adaptation at everyday level. So, insufficient level of Ukrainian language possession as mediator often becomes the reason of failures in professional education and practice. It is followed from the foregoing, that students' preparation for conducting of professional dialogue is extremely important during Ukrainian language as foreign one lessons, that conditions topicality of this investigation.

The development of professional dialogical communication comprises the list of special competences, formation of which must be provided by educational discipline called «Ukrainian language as foreign one». In particular, dialogical communication is a key competence of a medical student and it is outlined as «the ability to organize informative dialogue with elements of prescriptive dialogue, dialoguediscussion, using a developed tactic of lingual communication (to start and finish conversation at situations with different level of complexity, realize communicative tasks in verbal way and with the help of non-verbal means of communication; to specify details of a message of companions, to catch up and develop their opinion, to argue and recommend proper statements, considering «distances» in communication; to provide psychological comfort, generalize)» in exemplary program of the discipline of preparation of specialists of the second (master) level of education [Ukrainska mova yak inozemna: prymirna prohrama navchalnoi dystsypliny pidhotovky fakhivtsiv druhoho (mahisterskoho) rivnia vyshchoi osvity, 2017, p. 7]. The process of formation of this type of lingual competence provides the knowledge of necessary means and ways of expressing opinions and feelings by foreign students at different spheres of communication according to situations and topics, lingual acts, intentional programs, types of communicative organization of a discourse, etc.; ability to appropriately use language means at practice of live communication, reasonably choose verbal and non-verbal means for solving different communicative tasks; development of skills to establish and maintain the contact with a companion, to change lingual behavior depending on communicative situation.

It is necessary to note that development of dialogical communication as a component of formation of a special (professional, objective) lingual competence is an integral part of significantly wider concept - «sociocultural competence», that on the one hand is considered as «assimilation of cultural and spiritual values of proper and others' nations; norms that regulate relations between nations, centuries, genders, promotes aesthetic and morally-ethical development» in modern pedagogy [Melnychuk, Yatsyshyna, 2013, p. 153] and on the other hand as «the result of successful course of sociocultural adaptation - active process of interaction of representatives from another culture and environment, where they stay, the process of active acquirement of necessary working skills and knowledge for life, assimilation of basic norms, samples, values of new environment by a student» [Nesin, 2008, p. 121]. In addition, a complete bilateralism of communication is specificity of dialogical communication, that provides simultaneous training, speaking and listening and dialogical communication provides instantane- ous reaction on what was said before as well, because dialogical communication is characterized by unpredictability, knowledge of peculiarities of lingual etiquette, ability to form initiative remarks and understand elliptical syntactic constructions. All these specific features of dialogue conducting point into its special role in the process of professionally oriented education of Ukrainian language as foreign one at medical institutions of higher education. Dialoguequestioning is local focus of our investigation, as the most regular and demanded in medicinal practice.

Aim of investigation consists in theoretical grounding and experimental checking of method of conduction of professional dialogue-questioning as an important form of educational communication of a future doctor. Hypothesis of investigation consists in that modeled professional situation increases motivation to learn foreign language, gives a student the opportunity to chare obtained professional knowledge, promotes the development of dialogical communication, and its phased preparation and conduction are guarantees of successful conducting of a dialogue on the basis of thought-out system of tasks of situational character.

Method. The investigation is based on complex application of such methods as diagnostic ones (interviewing) and experimental ones (constant and forming experiment), method of theoretical analysis (during selection and consideration of separate aspects of dialogical communication, setting of questions and formulation of answers, peculiarities of Ukrainian lingual etiquette) and inductive method (during formulation of conclusions of investigation, obtained by empirical (experimental) way). Method of pedagogical observation and method of pedagogical experiment (pedagogical observation and experiment were implemented during conduction of practical lessons of Ukrainian language as foreign one at HSEI «Bukovynian state medical university»). The organization of investigation was conducted in three stages: original positions of investigation were developed and working hypothesis was formulated at the first (preparatory) stage; working hypothesis was checked on the basis of approbation of proposed method of conduction of a professional dialogue at lessons of Ukrainian language as foreign one at the second (basic) stage; analysis of results of experiment was implemented, in particular of qualitative and quantitative indicators of formation and development of dialogical communication at the final stage. The experiment covered 126 students of the fourth course of HSEI «Bukovynian state medical university».

Results and discussion. The essence of the proposed pedagogical experiment consists in comparison of skills of formed dialogical communication in the process of conduction of professional dialogue-questioning of the topic «At dermatological department» by such basic indicators as assimilation of active vocabulary, ability to build grammatically correct questions and meaningfully comprehensive answers, the speed of reaction, ability to express initiative questions. The part of students (62) mastered this topic during 4 hours by a traditional scheme of constructing dialogues in pairs «a doctor - a patient», herewith, the main part of educational time was paid to mastering of key questions and playing of these dialogues in pairs. The other part of students (64) worked on the basis of developed method of phased studying, that is described below. All the groups which were covered by the experiment differed ethnically and were similar by number (14-16 people), that's why, the impact of these indicators is insignificant on the result of experiment. 
We propose to apply phased approach to formation of these skills in the process of preparation of foreign medical students to conduction of a professional dialogue, it will include the following stages.

I. The stage of motivation. Insufficient level of motivation often becomes a reason of unavailability or low level of reproduction of dialogical communication, that's why, a teacher should clearly formulate basic goals and final aim of building of professional dialogue for a student, in particular, pay attention on the necessity to conduct such a dialogue during the whole process of studying. As the result, such type of dialogical communication can be considered as guarantee of professional growth. In addition, building of professional dialogue forms resistant model of both professional and social-ethical behavior. Conducted survey (in the form of questionnaire of opened type) of foreign students from the fourth course (in the amount of 126 students of different nationalities) of HSEI «Bukovynian state medical university» about basic difficulties in studying of Ukrainian language as foreign one gave us grounds to confirm, that the main obstacle was fear of talking with Ukrainian stranger in this language because of insufficiency of practical lingual skills at elementary stage of assimilation of Ukrainian language (54\% of respondents), while the minority called complicated grammatical system of Ukrainian language $(27 \%$, $18 \%$ of them considered fusion of Ukrainian language as basic grammatical difficulty, $9 \%$ of them considered difficulties with gender definition), $19 \%$ of respondents pointed on peculiarities of intercultural communication (lingual etiquette, fast rate of speaking of Ukrainians, phraseology). Taking into account these results, we can affirm, that modeling of educational situations will promote overcoming of psychological barrier in communication with Ukrainians as native speakers in the context of formation of skills of dialogical communication, as they will regularly reproduce typical models of situational communication, and it will allow students to practice lingual clichés, established questions, and so, to form lingual personality of a foreigner as confident speaker. So, such arguments as overcoming of fear of oral communication, fear of speaking in public, which are formulated by a teacher at elementary stage, as well as ability to apply a dialogue-questioning in everyday professional preparation, in particular, during conversation with patients in the course of studying of clinical disciplines and educational practices of different type can be considered as key «iron» arguments on the way of motivating students.

II. Assimilation of lexical minimum of professional vocabulary. It is necessary to concentrate main attention on lexical work at this stage, while grammatical and background-graphic skills will perform auxiliary function here.

It is appropriate to group lexical material into thematic fields, it is also advisable to distinguish typical lingualsyntactic constructions (key phrases, sentences) into their synonymous variability, for example: «What disturbs you?», «What are you complaining about?», «What is the reason of your appeal for a doctor?», etc. For example, while talking about the topic «At the dermatological department», it is proposed such a frequency vocabulary to a lexical minimum: икіра, де́рма, епіде́рміс, мелані́, пігме́нт, піт, за́лоза, боро́давка, змо́ршка, пухи́р, ро́димка, ву́гор, гній, гнійни́к, нари́в, фуру́нкул, трихо́лог, сальний, пружний, мімічний, пігментний.

In addition to lexical level, we propose to present the most frequent phraseological units at this stage, where «skin» to- ken is seen, as mastering of namely phraseological level of language is guarantee of formation of holistic lingual personality.

Exercise. Remember useful phrases. Explain how you understand their meanings. Make up sentences with them.

Мороз іде по шкірі; не влізтися в шкіру; зі шкіри пнутися; спускати шкіру; шкіра терпне; залити за шкіру сала.

A teacher should give examples of sentences with the aim of adequate understanding of meanings of these phraseologisms, in order a student see phraseological context, for example: Я так боюсь наступного екзамену з анатомії, щио мороз іде по шкірі. In order to form a stable habit to use these units, it is necessary to propose students to replace underlined word into a phraseologism in the next exercise ( $A x$ мед старався з усіх сил підготуватися до екзамену «Крок 1»).

The degrees of comparison of adjectives and adverbs are determined as topical grammar for this for this topic, which we propose to repeat on the example of sentences interesting facts about skin.

Exercise. Make up and write down degrees of comparison of adjectives and adverbs, which are presented in brackets.

Шкіра - цее (великий) орган людського тіла.

(Товстий) шкіра на ступнях ніг, а (тонкий) - на барабанних перетинках.

Веснянки (часто) з'являються в підлітковому віці, ніж у дорослих людей.

Шкіра, на якій є веснянки, (вразлива), ніж смугла.

На ліктях шкіра (суха) і (щуільна), ніж на інших ділянках тіла.

Клітини шкіри з віком оновлюються (повільно).

Люди з великою кількістю родимок (рідко) страждають на вікові захворювання.

Африканці та європейці мають (багато) кількість потових залоз, ніж азіати.

Після очшщення $i$ зволоження шкіра стає (әладка) $i$ (пружна).

The next part of lexical-grammatical exercises is directed into coordination of phrases in gender and number, as well as building of grammatically correct syntactic constructions.

Exercise. Make up all possible phrases (names of symptoms) with an example.

Example: жирність икіри

\begin{tabular}{|l|l|}
\hline Свербіж & нігті \\
\hline стоншення & тіло \\
\hline ламкість & голова \\
\hline лущення & волосся \\
\hline жирність & шкіра \\
\hline
\end{tabular}

Exercise. Make up sentences form the given words.

Людський/орган/найбільший/икіра/тіло.

Лікувати/икіра/хвороба/дерматолог.

Колір/меланін/ шкіра/визначає/i/волосся.

Сальні залози/себорея/порушення роботи/причина/це.

Основа/тканина/ие/білок/сполучний/колаген.

Захворюван-

ня/склеродермія/системний/тканина/сполучна.

It is important to teach students to formulate different types of questions at this stage: alternative, general (require only confirmation or objection) and special (with the help of inquiring words). The ability to formulate special questions is the most important for conducting a professional dialogue, 
as these questions perform the role of initiative remarks.

III. The development of monologue communication. This stage provides the development of students' ability to formulate own opinion about a certain problem. This monologue communication should be included into modeled intercourse of a doctor with a patient in the future, namely to become a logical part of a future professional dialogue. We propose such exercises for formation of skills of monologue communication:

Exercise. Replace infinitive of verbs into imperative form. Give recommendations to your friend.

Якщо у Вас багато родимок, візьміть до уваги такі медичні рекомендації:

- не можна засмагати на сониі;

- варто утикати засмаги у солярію;

родимки;

- заборонено використовувати хімічні розчини

для видалення родимок;

- $\quad$ не варто носити вузький одяг, який може травмувати родимку;

- варто спостерігати за змінами кольору, розміру родимок;

кожного року необхідно відвідувати дерматолога, щуоб зробити професійний огляд родимок.

We propose the exercise with text construction from the given sentences with the aim of formation of skills of logical building of syntactic units on the level of micro-text.

Exercise. Put a sentence in correct order. Write a number in a cell. Retell the formed text.

$\square$ Я побачив висип у себе на икірі.

$\square$ Лікар оглянув мене $і$ задумався.

$\square$ Через кілька днів висипка пройшла і я почувався повністю здоровим.

$\square$ Я пішов у лікарню на прийом до дерматолога.

$\square$ Я пішов в аптеку $і$ купив мазь та антигестамінні nрепаратu.

Пікар запитав мене, чи маю я алергію на медичні препарати, бо така висипка характерна для алергічних реакuiü.

Я розповів, щуо мене турбує.

$\square$ Він виписавмені мазь, антигестамінні препарати, а також призначив наступний прийом через тиждень.

IV. Modeling of professional situation. We completely share the opinion of T. Shevchuk (2018) here, that «in the process of speech learning, especially of unprepared one, it is important to pay attention on the role of situationality as means of stimulation and development of speech. A situation reproduces communicative reality and as follows, causes the interest to real communication in students-foreigners»» [Shevchuk].

At the elementary (socio-cultural) stage of language learning, it is important to propose different social situations for students, that are according to L. Vyhotskyi (1991) «absolutely original, specific, exceptional, singular and unique relations between a personality and outward reality, first of all social one» [Vyhotskyi, p. 241]. Social situations must be changed into professional ones at the stage of professionallyoriented education. However, modeling of professional situations sets new challenges in front of both students and teachers, especially of medical higher educational institutions, as modeling of such situations requires certain special medical knowledge from a pedagogue-philologist, at least for qualitative filling of frequency dictionary and work with medical terms system. Development of different variants of similar situation is another important moment of this stage, because same-type situations will reduce the level of communicative activity of a student. As the main aim of professional dialogue is to prepare a student for a conversation «a doctor - a patient» at Ukrainian language lessons, such model is the most acquitted, however there are also possible pairs, such as «a doctor - a doctor», «head doctor - a patient», «a nurse - a patient».

V. Distribution of roles and building of oral dialogue (spontaneous or prepared).

As 2 methods of formation of dialogical communication are selected in pedagogy, which are conditionally named «from above - downward» and «from below - upwards», we combine these two approaches in our experiment, as we use «from below - upwards» approach at elementary stages, then we propose to present complete dialogue at the stage of building of a dialogue itself, and to work with building of next ones on its basis and on its example. For example, we propose such types of exercises at this stage.

Exercise. Read a dialogue. Name a disease that is mentioned in the text. Name its symptoms.

Андрій: Добрий день, лікарю!

Лікар: Добрий день! Заходьте, будь ласка. Що Вас турбує?

Андрій: У мене проблема зі шкірою. На животі з'явились пухириі, і ия частина тіла постійно свербить.

Лікар: Лягайте на кушетку, я Вас огляну. Чи відчуваєте свербіж на внутрішній частині передпліччя?

Андрій: Так, там також є небагато пухириів.

Лікар: Коли вперше відчули свербіж і помітили утворення на шкірі?

Андрій: Учора, увечері.

Лікар: Можливо, Ви щось з '̈ли, що могло б викликати таку реакцію організму, а може, приймали нові ліки?

Андрій: Так, мені призначив терапевт новий комплекс вітамінів.

Лікар: Поки цуо потрібно відмінити цей препарат, оскільки ваш організм негативно зреагував на нього. Я випиму Вам таблетки і мазь від алергї. Також Ви повинні дотримуватися впродовж тижня дієти.

Андрій: А як же бути з вітамінами?

Лікар: Потрібно здати аналізи і визначити, на щуо у Вас алергія.

Андрій: Дякую за консультацію. До побачення.

Лікар: До побачення.

A student must complete a dialogue in the next exercise, using known vocabulary and words from the previous dialogue. Also such exercise requires knowledge and appropriate using of interrogative words from a student.

Exercise. Complete the dialogue.

Галина: Добрий день! Можна ввійти?

Лікар: Добрий день! Заходьте, будь ласка. Що Вас непокоїв?

Галина: Проблеми зі икірою а саме велика кількість вугрів.

Лікар: Покажіть мені обличчя. Скільки Вам років?

Галина: Мені 17.

Лікар: $\mathrm{Y}$ віці вугри з'являються внаслідок змін, шео відбуваються B

Галина: Як же боротися з иією проблемою?

Лікар: Насамперед, потрібно налагодити харчування і посилити догляд за Я Вам die- 
my $m a$ рекомендаиії по догляду за шкірою обличчя. Також приймайте впродовж п'яти днів протиалергічні ліки.

Галина: Чи варто робити чистку обличчя в косметолога?

Лікар: Поки щчо не робіть, тому щчо у Вас сильне запалення реду, на повторний

Галина: Дякую за рекомендащіï. До побачення.

Лікар: До побачення.

Exercise. Make up a dialogue, using remarks of a doctor and a patient.

\begin{tabular}{|c|c|}
\hline Лікар & Пацієнт \\
\hline Зрозуміло. А лупа у Вас $\epsilon$ ? & $\begin{array}{l}\text { Я буду виконувати все, щүо } \\
\text { Ви призначите. }\end{array}$ \\
\hline $\begin{array}{l}\text { Можна, але ие довготривалий } \\
\text { прочес. Потрібно приймати } \\
\text { препарати з вітаміни А, E, B, D, } \\
\text { а також сірку і цинк. Ходити на } \\
\text { фізіотерапевтичні процедури. } \\
\text { Дотримуватися дієти. }\end{array}$ & $\begin{array}{l}\text { Шкіра суха, лущиться, а } \\
\text { волосся сухе, ламке, часто } \\
\text { випадає. }\end{array}$ \\
\hline Добрий день! Як Вас звуть? & Чи можна ї̈ вилікувати? \\
\hline Що Вас турбує? & $\begin{array}{l}\text { Андрій, а до Вас як зверта- } \\
\text { тися? }\end{array}$ \\
\hline Яка саме? & $\begin{array}{l}\text { Дякую за консультацию. До } \\
\text { побачення. }\end{array}$ \\
\hline Микола Іванович! & Дуже приємно! \\
\hline До зустрічі в травні. & $\begin{array}{l}\text { Аякже, ше й дуже багато. } \\
\text { Жоден шампунь не допома- } \\
\text { гає. }\end{array}$ \\
\hline $\begin{array}{l}\text { Добре. Ось Вам рецепт і реко- } \\
\text { мендаиії. Через місяиь повтор- } \\
\text { ний огляд. }\end{array}$ & $\begin{array}{l}\text { У мене проблема зі шкірою } \\
\text { та волоссям. }\end{array}$ \\
\hline У Вас ознаки сухої себореї. & Добрий день! \\
\hline
\end{tabular}

At this stage, it is necessary to remember about periodic exchange of roles between students for their working out of typical doctor's questions and possible patient's answers. A teacher must pay attention of students on extra-linguistic means of communication, in particular, on rate of speech, intonation of interrogative phrases, gesticulation, etc. Formation of skills of logical thinking is one of the tasks of this stage through correct sequence of questions, search of cause and effect connections, distinguishing of main and minor. A teacher must differentiate questions of a doctor as general and specifying before the beginning of a dialogue on specific example.

VI. Construction of oral dialogue with written filling of medical card of a patient by a doctor. This stage is directed into development of oral speech in combination with development of writing skills. It is appropriately to divide filling of medical card into separate subdivisions («Passport information», «Complaints», «Life anamnesis» and so on) and develop them at separate lessons.

Conclusions. So, preparation of students-foreigners for conduction of professional dialogue at Ukrainian language as foreign one lessons is a continued process that provides students' motivation, mastering of basic vocabulary with its further inclusion into monologue communication, modeling of professional situation, distribution of roles of a doctor and a patient, preparation and playing of a dialogue with further filling of medical card of a patient. The form of role games enlivens and diversifies educational process and promotes professionally oriented education of Ukrainian language as foreign one in the process of preparation of a future highly qualified specialist.

The results of pedagogical experiment have confirmed efficiency of phased formation of skills of conducting of professional dialogue in pair «a doctor - a patient» by such basic indicators as 1) assimilation of active vocabulary (64\% before the experiment, $85 \%$ - after experiment), ability to construct grammatically correct questions and informatively comprehensive answers (51\% and $74 \%$ accordingly), the speed of reaction (62\% and $81 \%$ ), ability to express initiative questions (48\% and $78 \%$ ).

Prospects of further investigations are methodologypedagogical investigations of other types of a dialogue at higher medical school in this direction (dialogue-agreement, dialogue-consideration (discussion)), psychological peculiarities of conducting a dialogue in groups with different nations of foreign students.

\section{REFERENCES}

Ariyan, M. (2007). Lichnostno-oriyentirovannyy podkhod i obucheniye inostrannomu yazyku $\mathrm{v}$ klassakh s neodnorodnym sostavom obuchayemykh [Personality-oriented approach and teaching a foreign language in classes with a heterogeneous composition of students]. Inostrannyye yazyki $v$ shkole, (1), 11.

Bidenko, L., Bespalova G. (2017). Implementing audio-lingual method to teaching Ukrainian as a foreign language at the initial stage. Advanced Education, Issue 7, 23 -27.

Cervera, M.G., Cantabrana, J. L. (2015). Professional development in teacher digital competence and improving school quality from the teachers' perspective: a case study. New approaches in educational research, 4 (2), 115-122. https://doi.org/10.7821/naer.2015.7.123

Honcharenko, S. (1997). Ukrainskyi pedahohichnyi slovnyk. [Ukrainian pedagogical dictionary]. Kyiv: Lybid, https://hum.edu-lib.com/szbrannoe/goncharenko-s-uukrayinskiy-pedagogichniy-slovnik-onlayn

Melnychuk, I., Yatsyshyna, O. (2013). Osoblyvosti profesiinoi pidhotovky inozemnykh studentiv vyshchykh medychnykh navchalnykh zakladiv [Features of professional training of foreign students of higher medical educational institutions]. $\begin{array}{lll}\text { Uzhhorod: } & \text { Hoverla, } & \text { (27). }\end{array}$ https://dspace.uzhnu.edu.ua/jspui/handle/lib/1850

Nesin. Yu. (2008). Formuvannia sotsiokulturnoi kompetentsii starshoklasnykiv zasobamy inozemnoi movy [Formation of social and

cultural competence of high school students by means of a foreign language]. Molod i rynok. 10(45). 153-156.

Ovadiuk, O. V. (2015). Innovative methods as an important part of learning foreign languages. Advanced Education. 4, 45-50.

Passov, E. (2013). Metodicheskaya sistema inoyazyichnogo obrazovaniya kak adekvatnoe sredstvo razvitiya umeniya individualnosti vesti dIalog kultur [Methodical system of foreign language education as an adequate means of developing the individual skills to lead dialog of cultures]. Lipetsk, Russia: Lipetsk State Pedagogical University.

Sanjaya, D., Rahmah, S., Sinulingga, J., Lubis, A. A., \& Yusuf, M. (2014). Methods of Teaching Reading to EFL Learners: A Case Study. IJELS International Journal of Education and Literacy Studies, 2 (2), 9-14. https://doi.org/10.7575/aiac.ijels.v.2n.2p.9

Shevchuk, T. (2018). Profesiino spriamovane dialohichne movlennia $v$ protsesi navchannia studentiv-inozemtsiv [Professionally directed Dialogic speech in the process of teaching foreign students] http://kmp.fl.kpi.ua/ru/node/46.

Ukrainska mova yak inozemna: prymirna prohrama navchalnoi dystsypliny pidhotovky fakhivtsiv druhoho (mahisterskoho) rivnia vyshchoi osvity. (2017) [Russian as a foreign language: an exemplary program of the discipline of training specialists of the second (master's) level of higher education]. Kyiv, 154.

Vyhotskyi, L. (1991). Pedahohicheskaya psikholohiya [Educational psychology]. Moskow, Russia: Pedagogy. 